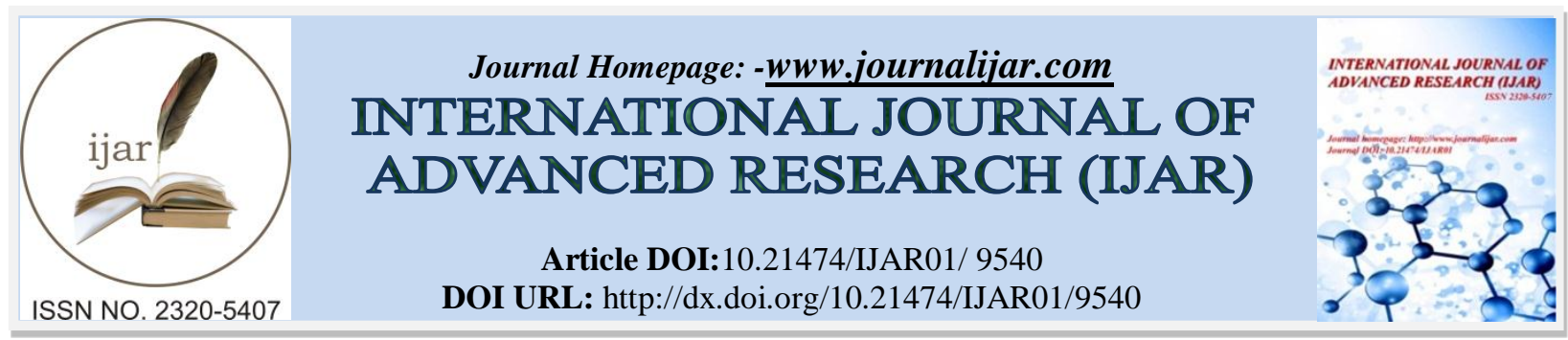

RESEARCH ARTICLE

\title{
IN VITRO ANTIBACTERIAL ACTIVITY OF COMBRETUM RACEMOSUM P. BEAUV (COMBRETACEAE) ON METHICILLIN-RESISTANT STAPHYLOCOCCUS AUREUS STRAINS.
}

Ouattara Karamoko ${ }^{1}$, Kamagaté Tidiane ${ }^{2}$, Ouattara Abou ${ }^{3}$ and N'Guessan Kouadio Emmanuel ${ }^{1}$.

1. Biochemical Pharmacodynamy Laboratory, Biosciences Department, Felix Houphouët Boigny University of Cocody, PO Box 582 Abidjan 22, Côte d'Ivoire.

2. Biotechnology Laboratory and Valorisation of Agro-resources, Biological Sciences faculty, Université Peleforo Gon Coulibaly of Korhogo, PO Box 1328 Korhogo, Côte d'Ivoire.

3. Department of Biochemistry and Microbiology, Agroforestry Faculty, University Jean Lorougnon Guede of Daloa, PO Box 150 Daloa, Côte d'Ivoire.

\section{Manuscript Info}

Manuscript History

Received: 08 June 2019

Final Accepted: 10 July 2019

Published: August 2019

Key words:-

Combretum racemosum, Staphylococcus aureus, aqueous extract, Hydro-ethanolic Extract.

\begin{abstract}
The purpose of this study was to evaluate the in vitro antibacterial activity of Combretum racemosum on 3 clinical strains of Staphylococcus aureus (S. aureus 1987C / 18, S. aureus 1989C / 18 and $S$. aureus 1994C / 18) and a strain of reference (S. aureus ATCC 29213). The effect of aqueous total extract and hydro-ethanolic 70\% extract of the plant on the growth of the strains was evaluated by determining the antimicrobial parameters by the method of wells in agar medium and by the method of microdilution in liquid medium. The aqueous total extract showed a better efficacy with a MIC ranging from $0.19 \pm 0 \mathrm{mg} / \mathrm{mL}$ to $0.78 \pm 0 \mathrm{mg} / \mathrm{mL}$ followed by hydroethanolic $70 \%$ extract with a MIC of $0,39 \pm 0 \mathrm{mg} / \mathrm{mL}$ at $1.56 \pm 0 \mathrm{mg} /$ $\mathrm{mL}$. The BMCs of the extracts ranged from $0.39 \pm 0 \mathrm{mg} / \mathrm{mL}$ to $1.56 \pm$ $0 \mathrm{mg} / \mathrm{mL}$ (aqueous total extract) and from $1.56 \pm 0 \mathrm{mg} / \mathrm{mL}$ to $3.12 \pm$ $0 \mathrm{mg} / \mathrm{mL}$ (hydro-ethanolic $70 \%$ extract). Both extracts showed a bactericidal effect on all the strains tested. These results suggest that $\mathrm{C}$. racemosum may be an alternative in the fight against Staphylococcus aureus infections.
\end{abstract}

Copy Right, IJAR, 2019,. All rights reserved.

\section{Introduction:-}

Bacterial infections alone account for $45 \%$ of deaths in developing countries and almost one in every two premature deaths worldwide with $70 \%$ of deaths caused by microorganisms (Walsh, 2003). Among the microorganisms responsible for these infections, there are those of the genus Staphylococcus including S. aureus. These germs cause serious skin infections, pneumonia and septicemia. All these infections require long stays in hospitals for patients with high mortality (Cosgrove $\boldsymbol{e t}$ al., 2003). These infections are treated with antibiotics. Indeed, antibiotics at the beginning of the twentieth century, have led to great advances in therapy and contributed to the rise of modern medicine. The introduction and clinical use of the first classes of antibiotics have significantly reduced mortality from previously incurable diseases. The effectiveness of antibiotic therapy in controlling and limiting the spread of pathogens has given rise to the hope of eradicating all infectious diseases (El amri et al., 2014). However, the massive and sometimes abusive use of antibiotics has significantly modified the microbial ecology thus increasing

Corresponding Author:-Kamagaté Tidiane.

Address:- Biotechnology Laboratory and Valorisation of Agro-resources, Biological Sciences faculty, Université Peleforo Gon Coulibaly of Korhogo, PO Box 1328 Korhogo, Côte d’Ivoire. 
the rate of bacteria resistant to several families of antibiotics like the $\beta$-lactams they were previously sensitive to (Guessennd et al., 2009). For example, half of all staphylococcus aureus in the United States are resistant to penicillin, tetracycline and erythromycin and especially to methicillin (Morrison et al., 2007). Resistance to the latter leads to resistance to all $\beta$-lactams (Guignard et al., 2005).

Faced with this phenomenon of antibiotic resistance and the many therapeutic failures, it therefore seems important to direct research towards other alternatives such as medicinal plant extracts to serve as a basis for obtaining new antibacterials (Zirihi et al., 2003). It is within this framework that we evaluated the antibacterial activity of extracts of the roots of Combretum racemosum P. Beauv. (Combretaceae) on methicillin-resistant Staphyloccocus aureus strains. Indeed, plants contain a large source of bioactive molecules that are usually part of secondary metabolites (Haddouchi et al., 2014). According to WHO (2002) estimates, more than $80 \%$ of the population in Africa still uses traditional medicine to meet their need for health care.

\section{Material and methods:- \\ Equipment \\ Microbial material}

The microbial material consists of 4 strains of Staphylococcus aureus including a reference strain (S. aureus ATCC 29213) and 3 clinical strains (S. aureus 1987C / 18, S. aureus 1989C / 18 and S. aureus 1994C / 18). All these strains were provided by the Institut Pasteur of Côte d'Ivoire.

\section{Plant material}

The roots of Combretum. racemosum were harvested in June 2018 in the department of Anyama (Ivory Coast). The plant has been authenticated at the National Center of Floristry of the Felix Houphouet Boigny University of Abidjan-Cocody where it is kept since July 17, 1985 under the No. 16949.

\section{Technical material}

The technical equipment used is composed of : a precision balance, a blinder, funnels, hydrophilic cotton, carded cotton, Whatman $3 \mathrm{~mm}$ filter paper to carry out the extractions. To this must be added the apparatus and glassware of use in a laboratory of Pharmacology and Microbiology.

\section{Methods}

Preparation of the vegetable powder

The roots of $C$. racemosum were harvested, washed with tap water, cut and dried under the sun at laboratory temperature $\left(25-30^{\circ} \mathrm{C}\right)$ for three weeks. After drying, they were sprayed with an electric grinder and the dry powder obtained was used to prepare the various extracts of the plant.

\section{Preparation of plant extracts}

Preparation of the aqueous total extract

The aqueous total extract (ATE) was prepared according to the method described by Ackah et al., (2008). In fact, $100 \mathrm{~g}$ of $C$. racemosum root powder were macerated in $1000 \mathrm{~mL}$ of distilled water by homogenization using a blinder. The homogenate obtained was first filtered on white fabric and then filtered twice on hydrophilic cotton and once on Whatman $3 \mathrm{~mm}$ filter paper. The filtrate obtained was dehydrated with an oven at $50{ }^{\circ} \mathrm{C}$. for 48 hours to obtain the aqueous total extract (ATE).

\section{Preparation of the hydroethanolic extract}

The hydroethanolic $70 \%$ extract (HEE) was also prepared according to the method described by Ackah et al., (2008). Again, $100 \mathrm{~g}$ of dry powder were macerated in $1000 \mathrm{ml}$ of $70 \%$ ethanol (700 ml pure ethanol). $+300 \mathrm{ml}$ of cold distilled water) by homogenization in a blinder. The homogenate obtained is first filtered on white fabric and then filtered twice on hydrophilic cotton and once on Whatman $3 \mathrm{~mm}$ filter paper. The filtrate obtained was dehydrated with an oven at $50^{\circ} \mathrm{C}$. for 48 hours to obtain the hydroethanolic $70 \%$ extract (HEE).

\section{Calculation of the yield of ATE and HEE extracts}

The yield (R) of each plant extract was determined. Indeed, it corresponds to the ratio between the mass of the extract obtained after evaporation of the solvent on the mass of plant powder used for the extraction multiplied by 100 grams (Dinzedi, 2015) according to the following formula : 


\section{Me x 100 \\ $\mathbf{R}(\%)=\frac{\mathrm{Mp}}{\mathrm{Mp}}$}

R: yield in \%; Me: mass in $\mathrm{g}$ of the extract obtained; Mp: mass in $\mathrm{g}$ of powder used for extraction

\section{Study of the antibacterial activity of the extracts of the plant \\ Preparation of the bacterial inoculum}

Two 18-hour joung colonies of each strain of $S$. aureus resistant to methicillin were removed using a platinum loop and then homogenized in $10 \mathrm{~mL}$ of physiological saline $(0.9 \% \mathrm{NaCl})$ and incubated during 3 hours at $37{ }^{\circ} \mathrm{C}$ to have a pre-culture. Then, $1 \mathrm{~mL}$ of the opalescent bacteria pre-culture broth was removed and diluted in a tube containing $9 \mathrm{~mL}$ of physiological saline $(0.9 \% \mathrm{NaCl})$ to obtain the bacterial inoculum at approximately $10^{6} \mathrm{CFU} / \mathrm{mL}$. In addition, a concentration range of each extract (ATE and HEE) ranging from $200 \mathrm{mg} / \mathrm{mL}$ to $1.56 \mathrm{mg} / \mathrm{mL}$ was prepared by the double dilution method in liquid medium for strain susceptibility testing (Ouattara et al., 2007).

\section{Strains susceptibility test with different plant extracts}

The sensitivity of the 4 strains of $S$. aureus was evaluated by the well method in Mueller-Hinton agar plate based on the diffusion of the antibacterial compound (plant extracts) with creation of a concentration gradient after a certain time of contact between the product and the target bacteria. For this, the Mueller-Hinton agar was uniformly seeded with $0.1 \mathrm{~mL}$ of the inoculum of each bacterial strain to be studied and then dried for $15 \mathrm{~min}$ at room temperature (22 ${ }^{\circ} \mathrm{C}$.). Then, wells approximately $6 \mathrm{~mm}$ in diameter were made in the agar plate in which $75 \mu \mathrm{L}$ of each plant extract (200 mg / mL, $100 \mathrm{mg} / \mathrm{mL}, 50 \mathrm{mg} / \mathrm{mL}, 25 \mathrm{mg} / \mathrm{mL}, 12.5 \mathrm{mg} / \mathrm{mL}, 6.25 \mathrm{mg} / \mathrm{mL}, 3.12 \mathrm{mg} / \mathrm{mL}, 1.56 \mathrm{mg} / \mathrm{mL}$ ) were deposited (Koffi et al., 2014). The agar was subsequently incubated in an oven at $37^{\circ} \mathrm{C}$ for 18 to 24 hours. After incubation, the effect of the extracts was appreciated by measuring an inhibition zone around each well which indicates antibacterial activity of the extract. Oxacillin $(6.25 \mathrm{mg} / \mathrm{mL}, 3.12 \mathrm{mg} / \mathrm{mL}, 1.56 \mathrm{mg} / \mathrm{mL}, 0.78 \mathrm{mg} / \mathrm{mL}$, $0.39 \mathrm{mg} / \mathrm{mL}, 0.19 \mathrm{mg} / \mathrm{mL}, 0.09 \mathrm{mg} / \mathrm{mL}, 0.05 \mathrm{mg} / \mathrm{mL}$ ) was used as the reference antibiotic (positive control).

\section{Determination of antimicrobial parameters}

Determination of Minimal Inhibitory Concentration (MIC)

The MIC of the different extracts was determined using the method described by Koné et al., (2004). For this, in hemolysis tubes, $1 \mathrm{~mL}$ of each concentration of extract as well as oxacillin as a positive control, was added to $1 \mathrm{~mL}$ of the inoculum $\left(10^{6} \mathrm{CFU} / \mathrm{ml}\right)$ leading to a halving of each concentration. Two other tubes, one without antibacterial agent served as growth control and the other without germ, for the control of sterility, were also prepared. All of these tubes were incubated at $37^{\circ} \mathrm{C}$ for 24 hours. The MIC corresponds to the concentration of the first tube which does not allow to observe visible growth of the germ tested after 18 hours to 24 hours of incubation at $37^{\circ} \mathrm{C}$.

\section{Determination of Minimal Bactericidal Concentration (MBC).}

For the determination of the MBC of the different extracts and for each strain, the bacterial inoculum was homogenized and then diluted $1 / 10$ to $10^{-4}$ dilution. Then, $2 \mu \mathrm{l}$ of the initial bacterial inoculum and the 4 successive dilutions were used to seed a Mueller-Hinton agar plate (box A) using a sterile platinum loop, on streaks of $5 \mathrm{~cm}$. long (Diaha, 1999). At the same time, $2 \mu \mathrm{L}$ of the tube contents in which no haze was observed from the tube corresponding to the MIC were seeded on the surface of a Mueller-Hinton agar (box B) also on $5 \mathrm{~cm}$ streaks. The $\mathrm{MBC}$ is determined after 24 hours incubation at $37^{\circ} \mathrm{C}$ by comparing the number of colonies of the box $\mathrm{B}$ with that of the box A. The concentration of the first experimental tube whose number of colonies was lower or equal to that of the $10^{-4}$ dilution of box A corresponds to the MBC. MBC is the lowest concentration of substance that leaves at most $0.01 \%$ of surviving germs after 24 hours of incubation at $37^{\circ} \mathrm{C}$. Finally, the antibacterial potential of the extracts was determined by calculating the MBC / MIC ratio. The extract is described as bactericidal if this ratio is less than or equal to 4 and bacteriostatic if this ratio is greater than 4 (Berche et al., 1991).

\section{Statistical analysis of the results}

The statistical analysis of the results was made from one-way ANOVA analysis followed by the Duncan test. All results obtained were expressed as mean \pm standard deviation $(n=3)$. Probability values $P<0.05$ were considered significant. All results were analyzed using the STATISTICA 7.1 software. 


\section{Results:-}

Yield of different extractions

The yield of the extractions varied according to the solvent used. In fact, for $100 \mathrm{~g}$ of plant powder used for extraction, the highest yield (18.50\%) was obtained with the hydroethanolic 70\% extract (HEE) followed by that of the aqueous total extract. (ATE) $(5.61 \%)$ with a significant difference between these yields $(\mathrm{P}<0.05)$.

\section{Determination of the antibacterial activity of plant extracts}

Sensitivity of strains to different extracts

Tables 1, 2 and 3 show the diameters of the zones of inhibition of the various extracts and of the reference molecule (Oxacillin). From these results, ATE and HEE had a strong inhibitory activity of $200 \mathrm{mg} / \mathrm{ml}$ to $6.25 \mathrm{mg} / \mathrm{ml}$ and $200 \mathrm{mg} / \mathrm{ml}$ to $12.5 \mathrm{mg} / \mathrm{ml}$, respectively. In fact, the inhibition diameters varied from $18.33 \pm 0.57 \mathrm{~mm}$ to $35 \pm 1$ $\mathrm{mm}$ (ATE) and from $10.33 \pm 0.57 \mathrm{~mm}$ to $25 \pm 1 \mathrm{~mm}$ (HEE) on all 4 bacterial strains. However, the inhibition of the strains by ATA remains greater than that of the HEE with a significant difference between the inhibition diameters of the two extracts.

As for Oxacillin (positive control), it also showed considerable areas of inhibition on the four bacterial strains studied with diameters between $16 \pm 0 \mathrm{~mm}$ and $36 \pm 0 \mathrm{~mm}$ for the different concentrations $(6.25$ to $0,09 \mathrm{mg} / \mathrm{mL})$. In addition, among all the bacterial strains studied, S. aureus strain 1994C / 18 seems to be the most sensitive to both extracts (ATE and HEE) with diameters of $35 \pm 1 \mathrm{~mm}$ and $25 \pm 1 \mathrm{~mm}$ respectively. In contrast, S. aureus 1989C / 18 was more sensitive ( $36 \pm 0$ ) than other strains with the reference antibiotic (oxacillin).

Table 1:-Diameters ( $\mathrm{mm}$ ) of zones of inhibition with aqueous total extract (ATE)

\begin{tabular}{|c|c|c|c|c|c|c|c|c|}
\hline \multirow[b]{2}{*}{ Bacterial strains } & \multicolumn{8}{|c|}{ Concentrations $(\mathrm{mg} / \mathrm{mL})$} \\
\hline & 200 & 100 & 50 & 25 & 12,5 & 6,25 & 3,12 & 1,56 \\
\hline $\begin{array}{l}\text { S. aureus } \\
\text { ATCC } 29213\end{array}$ & $\begin{array}{l}34 \\
\pm 1^{\mathrm{a}}\end{array}$ & $\begin{array}{l}31 \\
\pm 1^{\mathrm{a}}\end{array}$ & $\begin{array}{l}29,33 \\
\pm 0,57^{\mathrm{a}}\end{array}$ & $\begin{array}{l}27 \\
\pm 1^{\mathrm{a}}\end{array}$ & $\begin{array}{l}23,66 \\
\pm 1,52^{\mathrm{a}}\end{array}$ & $\begin{array}{l}20 \\
\pm 1^{\mathrm{a}}\end{array}$ & $0 \pm 0$ & $0 \pm 0$ \\
\hline $\begin{array}{l}\text { S. aureus } \\
1987 \mathrm{C} / 18\end{array}$ & $\begin{array}{l}34,66 \\
\pm 0,57^{\mathbf{b}}\end{array}$ & $\begin{array}{l}33 \\
\pm 1^{\mathbf{b}}\end{array}$ & $\begin{array}{l}31,33 \\
\pm 1,52^{\mathbf{b}}\end{array}$ & $\begin{array}{l}28 \\
\pm 1^{\mathrm{b}}\end{array}$ & $\begin{array}{l}24,66 \\
\pm 0,57^{b}\end{array}$ & $\begin{array}{l}22,66 \\
\pm 0,57^{b}\end{array}$ & $0 \pm 0$ & $0 \pm 0$ \\
\hline $\begin{array}{l}\text { S. aureus } \\
1989 \mathrm{C} / 18\end{array}$ & $\begin{array}{l}33,33 \\
\pm 0,57^{\mathbf{c}}\end{array}$ & $\begin{array}{l}29 \\
\pm 1^{\mathrm{c}}\end{array}$ & $\begin{array}{l}26 \\
\pm 1^{\mathrm{c}}\end{array}$ & $\begin{array}{l}24,33 \\
\pm 0,57^{\mathrm{c}}\end{array}$ & $\begin{array}{l}22,66 \\
\pm 0,57^{\mathfrak{c}}\end{array}$ & $\begin{array}{l}18,33 \\
\pm 0,57^{\mathrm{c}}\end{array}$ & $0 \pm 0$ & $0 \pm 0$ \\
\hline $\begin{array}{l}\text { S. aureus } \\
1994 \mathrm{C} / 18\end{array}$ & $\begin{array}{l}35 \\
\pm 1^{d}\end{array}$ & $\begin{array}{l}33,66 \\
\pm 0,57^{d}\end{array}$ & $\begin{array}{l}31,66 \\
\pm 0,57^{d}\end{array}$ & $\begin{array}{l}28,66 \\
\pm 1,52^{d}\end{array}$ & $\begin{array}{l}24,66 \\
\pm 1,52^{d}\end{array}$ & $\begin{array}{l}19,33 \\
\pm 1,15^{\text {d }}\end{array}$ & $0 \pm 0$ & $0 \pm 0$ \\
\hline
\end{tabular}

The averages are expressed with the standard deviations ( \pm ) values with the same letter with exponent in each of the columns are not significantly different $(\mathrm{p}<0.05)$.

Tableau 2:-Diameters (mm) of inhibition zones with hydro-ethanolic 70\% extract (HEE)\%)

\begin{tabular}{|l|l|l|l|l|l|l|l|l|}
\hline \multirow{2}{*}{ Bacterial strains } & $\mathbf{2 0 0}$ & $\mathbf{1 0 0}$ & $\mathbf{5 0}$ & $\mathbf{2 5}$ & $\mathbf{1 2 , 5}$ & $\mathbf{6 , 2 5}$ & $\mathbf{3 , 1 2}$ & $\mathbf{1 , 5 6}$ \\
\cline { 2 - 9 } S. aureus & 24,33 & 20 & 16,33 & 13,33 & 10,33 & $0 \pm 0$ & $0 \pm 0$ & $0 \pm 0$ \\
ATCC 29213 & $\pm 0,57^{\mathbf{a}}$ & $\pm 2^{\mathbf{a}}$ & $\pm 2,08^{\mathbf{a}}$ & $\pm 0,57^{\mathbf{a}}$ & $\pm 0,57^{\mathbf{a}}$ & & & \\
\hline S. aureus & 24,66 & 22,66 & 18,66 & 13,66 & 11,33 & $0 \pm 0$ & $0 \pm 0$ & $0 \pm 0$ \\
$\mathbf{1 9 8 7 C} / 18$ & $\pm 1,15^{\mathbf{b}}$ & $\pm 0,57^{\mathbf{b}}$ & $\pm 0,57^{\mathbf{b}}$ & $\pm 0,57^{\mathbf{b}}$ & $\pm 0,57^{\mathbf{b}}$ & & & \\
\hline S. aureus & 23 & 21,33 & 17,33 & 13 & 11 & $0 \pm 0$ & $0 \pm 0$ & $0 \pm 0$ \\
$\mathbf{1 9 8 9 C / 1 8}$ & $\pm 1^{\mathbf{c}}$ & $\pm 0,57^{\mathbf{c}}$ & $\pm 1,52^{\mathbf{c}}$ & $\pm 1^{\mathbf{c}}$ & $\pm 1^{\mathbf{c}}$ & & & \\
\hline S. aureus & 25 & 21,66 & 19,33 & 15 & 12 & $0 \pm 0$ & $0 \pm 0$ & $0 \pm 0$ \\
$\mathbf{1 9 9 4 C / 1 8}$ & $\pm 1^{\mathbf{d}}$ & $\pm 1,52^{\mathbf{d}}$ & $\pm 0,57^{\mathbf{d}}$ & $\pm 1,73^{\mathbf{d}}$ & $\pm 1^{\mathbf{d}}$ & & & \\
\hline
\end{tabular}

The averages are expressed with the standard deviations ( \pm ) values with the same letter with exponent in each of the columns are not significantly different $(\mathrm{p}<0.05)$.

Table 3:-Diameters (mm) of inhibition zones obtained with oxacillin (control)

\begin{tabular}{|l|l|l|l|l|l|l|l|l|}
\hline & \multicolumn{9}{|c|}{ Concentrations (mg/mL) } \\
\cline { 2 - 8 } Bacterial strains & $\mathbf{6 , 2 5}$ & $\mathbf{3 , 1 2}$ & $\mathbf{1 , 5 6}$ & $\mathbf{0 , 7 8}$ & $\mathbf{0 , 3 9}$ & $\mathbf{0 , 1 9}$ & $\mathbf{0 , 0 9}$ & $\mathbf{0 , 0 5}$ \\
\hline $\begin{array}{l}\text { S. } \text { aureus } \\
\text { ATCC 29213 }\end{array}$ & $33 \pm 0^{\mathbf{a}}$ & $30 \pm 0^{\mathbf{a}}$ & $28 \pm 0^{\mathbf{a}}$ & $24 \pm 0^{\mathbf{a}}$ & $21 \pm 0^{\mathbf{a}}$ & $18 \pm 0^{\mathbf{a}}$ & $0 \pm 0$ & $0 \pm 0$ \\
\hline S. aureus & & & & & & & & \\
\hline
\end{tabular}




\begin{tabular}{|l|l|l|l|l|l|l|l|l|}
\hline $\mathbf{1 9 8 7 C} / 18$ & & & & & & & \\
\hline $\begin{array}{l}\text { S. aureus } \\
\mathbf{1 9 8 9 C} / 18\end{array}$ & $36 \pm 0^{\mathbf{c}}$ & $33 \pm 0^{\mathbf{c}}$ & $29 \pm 0^{\mathbf{c}}$ & $25 \pm 0^{\mathbf{c}}$ & $22 \pm 0^{\mathbf{c}}$ & $16 \pm 0^{\mathbf{c}}$ & $0 \pm 0$ & $0 \pm 0$ \\
\hline $\begin{array}{l}\text { S. aureus } \\
\mathbf{1 9 9 4 C / 1 8}\end{array}$ & $34 \pm 0^{\mathbf{d}}$ & $31 \pm 0^{\mathbf{d}}$ & $27 \pm 0^{\mathbf{d}}$ & $24 \pm 0^{\mathbf{d}}$ & $20 \pm 0^{\mathbf{d}}$ & $20 \pm 0^{\mathbf{d}}$ & $18 \pm 0^{\mathbf{b}}$ & $0 \pm 0$ \\
\hline
\end{tabular}

The averages are expressed with the standard deviations ( \pm ) values with the same letter with exponent in each of the columns are not significantly different $(\mathrm{p}<0.05)$.

\section{Antibacterial parameters of plant extracts}

The antibacterial parameters (MIC, MBC) and the MBC / MIC ratio of the different extracts (ATE and HEE) of $C$. racemosum and the reference antibiotic (oxacillin) on the in vitro growth of the different strains are shown in Table 4 These results show that plant extracts and oxacillin have an inhibitory action on the growth of all strains of $S$. aureus tested. However, with the total aqueous extract (ATE), the clinical strains (S. aureus 1987C / 18, S. aureus $1989 \mathrm{C} / 18$ and $S$. aureus $1994 \mathrm{C} / 18)$ were the most sensitive recording the same MIC values $(0,19 \pm 0 \mathrm{mg} / \mathrm{mL})$ and MBC $(0.39 \pm 0 \mathrm{mg} / \mathrm{mL})$ compared to the reference strain (S. aureus ATCC 29213) with MIC $=0.78 \pm 0 \mathrm{mg} /$ $\mathrm{mL}$ and $\mathrm{MBC}=1.56 \pm 0 \mathrm{mg} / \mathrm{mL}$. Furthermore, the ratio of MBC / MIC of the ETA on all the strains was 2 thus showing a bactericidal effect of this extract on these strains.

For HEE, the determined MIC was identical to MBC for S. aureus strains ATCC $29213(1.56 \pm 0 \mathrm{mg} / \mathrm{mL})$ and $S$. aureus $1987 \mathrm{C} / 18(0.39 \pm 0 \mathrm{mg}) . / \mathrm{mL})$. With the S. aureus 1989C / 18 and S. aureus 1994C / 18 strains, the MIC values were $0.78 \mathrm{mg} / \mathrm{mL}$ and $1.56 \mathrm{mg} / \mathrm{mL}$, respectively, while the $\mathrm{MBC}$ values were $1,56 \pm 0 \mathrm{mg} / \mathrm{mL}$ for $S$. aureus $1989 \mathrm{C} / 18$ and $3.12 \pm 0 \mathrm{mg} / \mathrm{mL}$ for S. aureus $1994 \mathrm{C} / 18$. The MBC/ MIC ratio for all of these strains was less than 4 also showing a bactericidal effect of HEE.

As for the reference antibiotic (oxacillin), the results showed that the strains of S. aureus 1989C / 18 and S. aureus 1994C / 18 recorded the same MICs $(0.78 \pm 0 \mathrm{mg} / \mathrm{mg} / \mathrm{mL})$ and MBCs $(1.56 \pm 0 \mathrm{mg} / \mathrm{mg} / \mathrm{mL})$. For the $S$. aureus strain ATCC / 29213, the observed MIC value was identical to that of MBC (1.56 $\pm 0 \mathrm{mg} / \mathrm{mL})$. In contrast, the MIC $(1.56 \pm 0 \mathrm{mg} / \mathrm{mL})$ and MBC $(3.12 \pm 0 \mathrm{mg} / \mathrm{mL})$ values recorded were greater with the S. aureus 1987C / 18 strain. The MBC / MIC ratios being less than 4 for all strains, oxacillin also had a bactericidal effect.

Table 4:-Parameters and antibacterial powers of plant extracts

\begin{tabular}{|c|c|c|c|c|c|}
\hline \multirow[t]{2}{*}{ Bacterial strains } & \multirow[t]{2}{*}{ Extracts } & \multicolumn{2}{|c|}{$\begin{array}{l}\text { Antibacterial parameters }(\mathrm{mg} \\
/ \mathrm{mL})\end{array}$} & \multirow{2}{*}{$\begin{array}{l}\text { Efficiency } \\
\text { report } \\
\text { (MBC/MIC) }\end{array}$} & \multirow[t]{2}{*}{$\begin{array}{l}\text { antibacterial } \\
\text { power }\end{array}$} \\
\hline & & MIC & MBC & & \\
\hline \multirow{3}{*}{$\begin{array}{l}\text { S. aureus } \\
\text { (ATCC/29213) }\end{array}$} & ATE & $0,78 \pm 0,00^{\mathrm{a}}$ & $1,56 \pm 0,00^{\mathrm{a}}$ & 2 & Bactéricide \\
\hline & HEE & $1,56 \pm 0,00^{b}$ & $1,56 \pm 0,00^{\mathrm{a}}$ & 1 & Bactéricide \\
\hline & Ox & $1,56 \pm 0,00^{b}$ & $1,56 \pm 0,00^{\mathrm{a}}$ & 1 & Bactéricide \\
\hline \multirow{3}{*}{$\begin{array}{l}\text { S. aureus } \\
1987 \mathrm{C} / 18\end{array}$} & ATE & $0,19 \pm 0,00^{\mathbf{c}}$ & $0,39 \pm 0,00^{\mathbf{b}}$ & 2 & Bactéricide \\
\hline & HEE & $0,39 \pm 0,00^{\mathrm{d}}$ & $0,39 \pm 0,00^{b}$ & 1 & Bactéricide \\
\hline & Ox & $1,56 \pm 0,00^{b}$ & $3,12 \pm 0,00^{\mathbf{c}}$ & 2 & Bactéricide \\
\hline \multirow{3}{*}{$\begin{array}{l}\text { S. aureus } \\
1989 \mathrm{C} / 18\end{array}$} & ATE & $0,19 \pm 0,00^{\mathbf{c}}$ & $0,39 \pm 0,00^{\mathbf{b}}$ & 2 & Bactéricide \\
\hline & HEE & $0,78 \pm 0,00^{\mathrm{a}}$ & $1,56 \pm 0,00^{\mathrm{a}}$ & 2 & Bactéricide \\
\hline & Ox & $0,78 \pm 0,00^{\mathrm{a}}$ & $1,56 \pm 0,00^{\mathbf{a}}$ & 2 & Bactéricide \\
\hline \multirow{3}{*}{$\begin{array}{l}\text { S. aureus } \\
1994 \mathrm{C} / 18\end{array}$} & ATE & $0,19 \pm 0,00^{\mathbf{c}}$ & $0,39 \pm 0,00^{\mathbf{b}}$ & 2 & Bactéricide \\
\hline & HEE & $1,56 \pm 0,00^{\mathbf{b}}$ & $3,12 \pm 0,00^{\mathbf{c}}$ & 2 & Bactéricide \\
\hline & Ox & $0,78 \pm 0,00^{\mathrm{a}}$ & $1,56 \pm 0,00^{\mathrm{a}}$ & 2 & Bactéricide \\
\hline
\end{tabular}

ATE : aqueous total extract ; HEE : hydro-ethanolic 70\% extract ; Ox: Oxacillin, MIC: minimal inhibitory concentration ; MBC: Minimal Bactericidal Concentration. Averages are expressed with standard deviations $( \pm)$. Values with the same superscript letter in each of the columns are not significantly different $(\mathrm{p}<0.05)$.

\section{Discussion:-}

The purpose of this study was to evaluate the antibacterial activity of aqueous and ethanolic C. racemosum extracts on the in vitro growth of four methicillin-resistant strains of $S$. aureus. The results show that the HEE (18.50\%) yield was higher than the ATE (5.61\%). The variation in yields could be explained by the chemical content of the plant, which can be extracted by each solvent used (Adjou \& Soumanou, 2013). Indeed, the amount of extractable bioactive molecules in the plant depends on the extraction method and the ability of the solvent to dissolve the 
endogenous compounds (Sultana $\boldsymbol{e t}$ al., 2009, Kamarudin $\boldsymbol{e t}$ al., 2016). This confirms the results of work on the leaves of Annona senegalensis (Traore et al., 2012), Terminalia arjuna (Sultana et al., 2009) and Clerodendrum splendens (Kouadio et al., 2013).

Regarding the antibacterial potential, the results showed that root extracts of the plant inhibited strains of $S$. aureus, indicating that this plant has significant in vitro antibacterial properties. In fact, the inhibition diameters recorded varied from $18.33 \pm 0.57$ to $35 \pm 1 \mathrm{~mm}$ for the ATE and from $10.33 \pm 0.57$ to $25 \pm 1 \mathrm{~mm}$ for the HEE. According to Ponce et al., (2003), an extract is considered active if it induces an inhibition zone greater than or equal to $9 \mathrm{~mm}$. As a result, both extracts used were active on $S$. aureus strains tested at concentrations of $6.25 \pm 0 \mathrm{mg} / \mathrm{mL}$ for ATE and $12.5 \pm 0 \mathrm{mg} / \mathrm{mL}$ for HEE. However, of the two extracts, ATE was more effective on bacterial strains inducing higher inhibition diameters between $33.33 \pm 0.57$ and $35 \pm 1 \mathrm{~mm}$ on the $S$. aureus at the 200 concentration. $\mathrm{mg} / \mathrm{mL}$. Analysis of the results shows that the sensitivity of each strain tested remains related to the concentration of the extract used in a dose-response relationship.

Regarding the antibacterial power, the evaluation of the extracts of plants tested by the dilution method revealed that these extracts have a significant antibacterial capacity on all the strains studied with MICs ranging from $0.19 \pm 0 \mathrm{mg}$ / $\mathrm{mL}$ to $1.56 \pm 0 \mathrm{mg} /$ for ATE and from $0.39 \pm 0 \mathrm{mg} / \mathrm{mL}$ to $1.56 \mathrm{mg} / \mathrm{mL}$ for HEE. Moreover, the ratio of MBC / MIC activity expressing the bacterial potency of the two extracts of C. racemosum varied from 1 to 2 . According to Berche et al. (1991), when this report concerning a substance is less than or equal to 4, this substance is considered bactericidal and when it is greater than 4 , it is said to be bacteriostatic. If we stick to these authors, all extracts tested have a bactericidal action on all strains studied. The antibacterial activity of $C$. racemosum extracts is related to the presence of bioactive molecules in these extracts. Moreover, several studies have been conducted in this direction. Indeed, a phytochemical sorting of the extracts of this plant by Onocha et al. (2005); Okwuosa et al. (2012) and Kamou et al. (2016) revealed that it contains alkaloids, phenolics, saponins, cardiotonic glycosides, sterols and polyterpenes in abundance. All these classes of molecules are known for their antibacterial properties (Bruneton, 1993, Bssaibis et al., 2009, Tiwari $\boldsymbol{e t}$ al., 2011). These molecules could therefore be responsible for the inhibitory activity of $C$. racemosum on different strains of $S$. aureus resistant to methicillin. Therefore this plant could be recommended in the fight against infections caused by these strains.

\section{Conclusion:-}

At the end of this study, which evaluated the effect of the roots of Combretum racemosum, we note that the results showed that the two extracts tested inhibited all bacterial strains in a dose-dependent relationship with a bactericidal effect on all of these strains. In addition, the aqueous total extract was the most active compared to the hydroethanolic $70 \%$ extract. It would be important to optimize the process of extraction and identification of the active ingredients of this plant for use in vivo against infections caused by strains of $S$. aureus.

\section{Acknowledgments:-}

Our thanks are addressed to the Pasteur Institute of Cocody (Ivory Coast) and to the National Floristic Center of Félix Houphouet Boigny University of Cocody-Abidjan (Ivory Coast) for their technical assistance.

\section{Conflict of interest statement}

The authors declare no conflict of interest in this article.

\section{References:-}

1. Ackah AJ., Kra AM., Zirihi GN. \& Guédé-Guina F. (2008) : Evaluation of the antifungal activity of tekam, a plant extract, on the in vitro growth of candida albicans. Rev Ivoir Technol Saw, 11 : 119-129.

2. Adjou ES. \& Soumanou M.M. (2013) : Efficacy of plant extracts in the fight against post-harvest toxinproducing peanut mold in Benin. Appl Journ Bioscie, 70 : 5555-5566.

3. Bruneton J. (1993) : Pharmacognosy: phytochemistry, plant med, 581.634 B7.

4. Bssaibis F., Gmira N. \& Meziane M. (2009) : Antibacterial activity of Dittrichia viscosa (L.) W. Greuter. Rev Microbiol Indus, Sant Envir, 3 : 44-55.

5. Cosgrove SE, Sakoulas G, Perencevich EN. (2003) : Methicillin-resistant and Methicillin-susceptible Staphylococcus aureus bacteremia: a meta-analysis. Clinic Infect Dis ; 36 : 53-59. 
6. Diaha KH. (1999) : Epidemiosurveillance of antibiotic resistance of the Bacterial Ecosystem in Abidjan in 1997. State Thesis in Medicine. Faculty of Medical Sciences, University of Cocody (Abidjan, Ivory Coast), 196 p.

7. Dinzedi MR., (2015) : Antibacterial activities of extracts of terminalia catappa and thonningia sanguinea on Escherichia coli, klebsiella pneumoniae and multiresistant staphylococcus aureus of human origin. Ph.D. thesis of Félix Houphouët-Boigny University, Abidjan, Ivory Coast, pp 2-36.

8. El Amri J., Elbadaoui K., Zair T., Bouharb H., Chakir S. \& Alaoui TI. (2014) : Study of the antibacterial activity of Teucrium capitatium L essential oils and Silene vulgaris extract on various strains tested. Journ Appl Bioscie, 82 (1) : 7481-7492.

9. Guessennd N., Gbonon VC., Tiékoura KB., Kakou-N'douba A., Ouattara DN., Boni-Cissé C., Dosso M. \& GER-BMR. (2009) : Evolution of bacterial resistance to imipenem in Côte d'Ivoire from 2005 to 2009. Scientific symposium of the Pasteur Institute of Côte d'Ivoire : emerging pathologies and integrative biology, $\mathrm{p}$ 17.

10. Guignard BJ, Entenza M. \& Moreillon P. (2005) : Beta-lactams against methicillin resistant Staphylococcus aureus. Cur Op Pharm, 5 : 479-489.

11. Haddouchi F., Chaouche TM. \& Ksouri R. (2014) : Phytochemical screening and in vitro antioxidant activities of aqueous extracts of Helichrysum stoechas subsp. rock and Phagnalon saxatile subsp. saxatile. Chin Journ Nat Med, 12 (6) : 415-22.

12. Kouadio FK, Guessennd NK, Ouattara K, Bahi C, Coulibaly A, Dosso M. (2013) : Antibacterial action of 70\% ethanol extract of Clerodendrum splendens (G. Don) (Verbenacae) on bacterial strains isolated from stool in diarrheal children. Int Day Biol Chem Saw, 7 (3) : 1332-1337.

13. Kamarudin NA, Markom M. \& Latip J. (2016) : Effects of Solvents and Extraction

14. Methods on Herbal Plants Phyllanthus niruri, Orthosiphon stamineus and Labisia pumila. Ind Journ Saw Tech. ; $9(21): 1-5$.

15. Kamou KR., Nanga YZ., Ouattara A., Kambou SP., Gnahoue G., Bahi C. \& Coulibaly A. (2017) : Superficial anticandidosic activity of leaves of Combretum racemosum P. Beauv. (Combretaceae) extracts. Dr. Deliv Therap Day, 7 (5) : 53-60.

16. Koffi AC., Koffi-Nevry R., Kouassi KC. \& Loukou YG. (2014) : Activity of extracts of six varieties of pepper (Capsicum) used in Ivory Coast. Journ Appl Bioscie, 82 : 7379-7388.

17. Koné WM., Kamanzi AK., Terreaux C., Hostettmann K., Traore D. \& Dosso M. (2004) : Traditional medicine in North Ivory Coast: Screening of 50 medicinal plants for antibacterial activity. Journals Ethnopharm, 93 : 4349.

18. Morrison MA, Nadle J. (2007) : Invasive methicillin-resistant staphylococcal aureus infections in the United States. JAMA, $298: 1763-1771$.

19. WHO (2002) : Report on Traditional Medicine : Needs and Potential. 6 p.

20. Okwuosa CN., Unekwe PC., Nwobodo E. \& Chilaka (2006) : The anti-ulcer activities of the leaf extract of Combretum racemosum (Combretaceae). Journ Biomed Invest, 4 : 8-14.

21. Onocha PA., Audu EO., Ekundayo O. \& Dosumu (2005) : Phytochemical and antimicrobial properties of extracts of Combretum racemosum. Act Horticult, 675 : 97-101.

22. Ouattara K., Djaman A J., Coulibaly A., N'guessan JD., M'baiasbe YJ., Guede-Guina F. (2007) : Antibacterial activity of Thonningia sanguinea (THOS) on Salmonella enterica serotype enteritidis phage 6, a multi-resistant strain. Rev Med Pharmac Afr; 20: 1-8.

23. Ponce AG, Fritz R., Del Alle C. \& Roura SI. (2003) : Antimicrobial activity of essential oil on the native microflora of organic Swiss chard. Lebensml-Wissensch Technol, 36 : 679-684

24. Sultana B., Anwar F. \& Ashraf M. (2009) : Effect of solvent extraction / technique on the antioxidant activity of selected medicinal plant extracts. Mol, 14 (6) : 2167-2180. 28.

25. Tiwari P., Kumar B., Kaur M., Kaur G. \& Kaur H. (2011) : Phytochemical screening and extraction : a review. Inter pharm saw, $1: 98-106$.

26. Traore Y., Ouattara K., Yeo D., Doumbia I. \& Coulibaly A. (2012) : Antifungal and antibacterial activities of the leaves of Annona senegalensis Pers (Annonaceae). Journ Appl Bioscie, 58 : 4234-4242.

27. Walsh C. (2003). Antibiotics: Actions, Origins, Resistance. ASM Press: Washington, D.C

28. Zirihi GN., Kra AKM. \& Guédé-Guina F. (2003) : Evaluation of the antifungal activity of Microglossa pyrifolia (Larmarck) O. kuntze (Asteraceae) "pymi" on the in vitro growth of Candida albicans. Rev Med Pharm Afr, 17 : 11-1. 